$1-1-2013$

\title{
State Interests and the Duration of Abortion Rights
}

Randy Beck

University of Georgia School of Law, rbeck@uga.edu

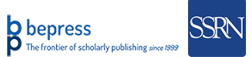

\section{Repository Citation}

Randy Beck, State Interests and the Duration of Abortion Rights , 44 McGeorge L. Rev. 31 (2013),

Available at: https://digitalcommons.law.uga.edu/fac_artchop/914

This Article is brought to you for free and open access by the Faculty Scholarship at Digital Commons @ University of Georgia School of Law. It has been accepted for inclusion in Scholarly Works by an authorized administrator of Digital Commons @ University of Georgia School of Law. Please share how you have benefited from this access For more information, please contact tstriepe@uga.edu. 


\title{
State Interests and the Duration of Abortion Rights
}

\author{
Randy Beck*
}

\section{TABLE OF CONTENTS}

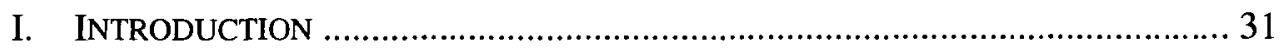

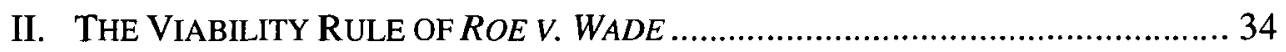

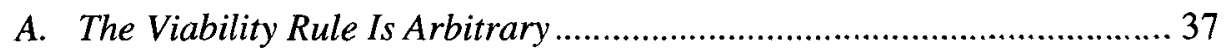

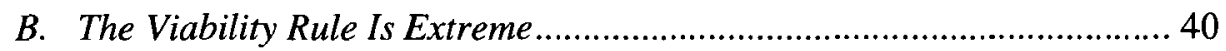

III. JUSTICE KENNEDY AND THE VIABILITY RULE.......................................... 42

A. Webster v. Reproductive Health Services ................................................ 42

B. Planned Parenthood of Southeastern Pennsylvania v. Casey .................. 44

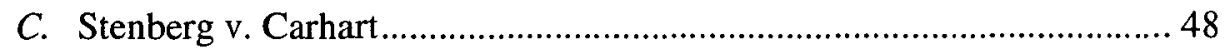

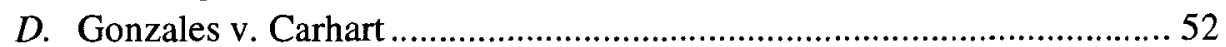

E. Justice Kennedy and the Future of the Viability Rule ............................ 54

1. New State Interests and the Duration of Abortion Rights................. 54

2. Stare Decisis and the Duration of Abortion Rights .......................... 56

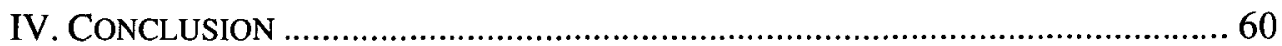

\section{INTRODUCTION}

Few areas of the Supreme Court's jurisprudence have attracted as much attention in recent decades as the case law recognizing a constitutional right to terminate a pregnancy. Justice Anthony $M$. Kennedy has exercised more influence over the Court's abortion jurisprudence than perhaps any other sitting Justice. His jointly authored plurality opinion in Planned Parenthood of Southeastern Pennsylvania v. Casey' reaffirmed the basic right to an abortion

* Justice Thomas O. Marshall Chair of Constitutional Law, University of Georgia School of Law. While I had the chance to clerk for Justice Kennedy during the October $1990 \mathrm{Term}$, an opportunity for which I remain very grateful, the ideas expressed in this Article are based on Justice Kennedy's published opinions. I have not spoken with Justice Kennedy about these issues and do not possess any nonpublic information on his views. I would like to thank Ash Bhagwat, Clarke Forsythe, Judson Shelnutt, and John Thorp for commenting on portions of the Article. I also appreciate feedback and editing suggestions from the editors of the McGeorge Law Review and other participants in the symposium on "The Evolution of Justice Anthony M. Kennedy's Jurisprudence."

1. 505 U.S. 833 (1992) (O'Connor, Kennedy, \& Souter, JJ., plurality). 
first recognized in Roe v. Wade, applying that right to regulations effective from the outset of pregnancy. ${ }^{3}$ Subsequent opinions, particularly Justice Kennedy's dissent in Stenberg v. Carhart ${ }^{4}$ and his majority opinion in Gonzales v. Carhart, ${ }^{5}$ have instead focused on regulations applicable to abortions performed in the second or third trimesters of pregnancy. ${ }^{6}$

Justice Kennedy's more recent opinions may suggest that we have not heard the last word on state regulation of late-term abortions. The reasoning of Justice Kennedy's opinions in Stenberg and Gonzales casts doubt on the justification for the dicta in Roe and Casey indicating that the constitutional right to abortion continues until a fetus is "viable" (that is, able to survive outside the womb with medical assistance). ${ }^{7}$ The Court has never offered an adequate constitutional justification for the viability rule, ${ }^{8}$ a line that produces arbitrary and irrational results, pushes U.S. law outside the international mainstream, and prevents the development of a stable political consensus on abortion regulation. It remains to be seen what Justice Kennedy will do if a future case requires the Court to squarely address the duration of abortion rights. 'While his opinions in Stenberg and Gonzales are written in such a way that the Court could continue adherence to the viability rule, they also make clear that Justice Kennedy finds secondtrimester abortions troubling and recognizes legitimate grounds for state regulation at that stage of pregnancy. ${ }^{10}$

Justice Kennedy's opinions leave open at least two paths by which the Court might afford states greater flexibility in regulating second-trimester abortions. First, Justice Kennedy's opinion in Gonzales (especially when read in light of his Stenberg dissent) permits states to justify abortion regulations based on novel state interests distinct from the two recognized in Roe (protecting fetal life and maternal health)." There is no reason that the viability rule, developed in the

2. 410 U.S. 113,164 (1973).

3. Casey, 505 U.S. at 846.

4. 530 U.S. 914, 956-79 (2000) (Kennedy, J., joined by Rehnquist, C.J., dissenting).

5. 550 U.S. $124,130-68$ (2007).

6. Id. at 133-40; Stenberg, 530 U.S. at 924-28.

7. See infra notes 181-86 (discussing the future of the viability rule in light of Stenberg and Gonzales).

8. See Hamilton v. Scott, No. 1100192, slip op. at 21-47 (Ala. May 18, 2012) (Parker, J., concurring) (questioning rationale for Roe's viability rule while explaining its inapplicability in wrongful death case). While the Roe court first announced the viability rule as dictum, the Court has since applied it in other cases. See, e.g., Colautti v. Franklin, 439 U.S. 379 (1979). Nevertheless, the duration of abortion rights has never been "squarely addressed" on the basis of plenary briefing and argument. See, e.g., Brecht v. Abrahamson, 507 U.S. 619, 631 (1993) (stare decisis did not bar reconsideration of rule applied in prior cases where issue never "squarely addressed"). As a result, the Court has never adequately explained its rationale for the viability rule.

9. Throughout this Article, the phrase "duration of abortion rights" refers to the courts' determination of the stage in pregnancy at which the Constitution permits governmental regulations that create a substantial obstacle to abortion.

10. See infra Parts III.C-D.

11. Gonzales, 550 U.S. at 157-58; see also Stenberg, 530 U.S. at 956-79; Roe v. Wade, 410 U.S. 113 , 163 (1973). 
context of the particular state interest in protecting potential life, would necessarily govern all of the new state interests Gonzales permits. ${ }^{12}$

Second, it may be time to revisit the viability rule or, more accurately, to finally consider its validity for the first time on the basis of plenary briefing and argument. The Court adopted the viability rule in dicta in $R o e^{13}$ and reaffirmed it in dicta in Casey. ${ }^{14}$ Consequently, the Court has not grappled with the duration of abortion rights in a case where the answer mattered to the outcome. ${ }^{15}$ The result has been the Court's longstanding failure to explain why the capacity to survive outside the womb should be required as a constitutional matter before a state can protect the life of a second-trimester fetus. These factors-adoption in dicta, inadequacy of briefing and argument, and failure to offer a convincing rationale-have long been viewed as undercutting the precedential weight of rules announced in prior opinions. ${ }^{16}$

Moreover, the pragmatic considerations that persuaded the Casey plurality to retain the right to an abortion weigh in favor of reconsidering the viability rule. ${ }^{17}$ For instance, the Court has acknowledged "the uncertainty of the viability determination," regulate medical practice. Likewise, while some women may rely on the availability of abortion in making decisions about relationships and career paths, it is implausible that many substantially rely on the viability rule's extension of abortion rights through most of the second trimester of pregnancy. Consequently, the Court's stare decisis opinions would support reconsideration of the duration of abortion rights in a case that squarely presented the issue. ${ }^{19}$

Part II of this Article considers the Court's adoption of the viability rule in Roe and highlights various problems the rule creates. Part III surveys Justice Kennedy's positions in several cases, with a particular focus on the implications of his opinions for regulating late-term abortions and the continuing force of the viability rule.

12. See Gonzales, 550 U.S. at $157-58 ;$ Roe, 410 U.S. at 163.

13. Roe, 410 U.S. at $163-64$.

14. Planned Parenthood of Se. Pa. v. Casey, 505 U.S. 833, 846 (1992) (O'Connor, Kennedy, \& Souter, JJ., plurality).

15. See Randy Beck, Transtemporal Separation of Powers in the Law of Precedent, 87 NOTRE DAME L. REV. 1405, 1460-63 (2012) [hereinafter Beck, Transtemporal Separation of Powers].

16. See id. at $1460-64$.

17. See infra notes $197-223$ and accompanying text.

18. Colautti v. Franklin, 439 U.S. 379, 395 (1979).

19. See Brecht v. Abrahamson, 507 U.S. 619, 631 (1993). 


\section{THE VIABILITY RULE OF ROE V. WADE}

In determining the precedential effect of judicial opinions, we distinguish holding and dictum because we expect judges to do a better job of resolving a dispute currently before the court than in anticipating future cases with unknown litigants and unforeseen facts. ${ }^{20}$ The record of a case informs judges about the pending litigation, but may have little relevance for future cases. ${ }^{2 !}$ The parties' briefs focus the court on issues raised in the ongoing dispute, but may provide no assistance on issues likely to arise in subsequent cases. ${ }^{22}$ In recent articles, therefore, I have argued that the Justices of the Supreme Court took a significant misstep when they decided to include extensive dicta in Roe v. Wade focusing on the duration of abortion rights, an issue the parties neither briefed nor argued. ${ }^{23}$ The Texas statute in Roe and the Georgia statute at issue in the companion case of Doe v. Bolton regulated abortions in the early stages of pregnancy. ${ }^{24}$ Neither case forced the Justices to confront the distinct issues and the grim realities that arise when clinicians perform abortions later in the process of gestation. ${ }^{25}$ The Roe Court's decision to draw durational lines was therefore premature and poorly executed. $^{26}$

The first drafts of Roe and Doe made no attempt to address the duration of abortion rights. ${ }^{27}$ Following the initial argument to a seven-Justice Court, Justice Blackmun circulated an opinion in Roe that would have invalidated the Texas statute on vagueness grounds and an opinion in Doe that would have struck down

20. See Beck, Transtemporal Separation of Powers, supra note 15, at 1418; Pierre N. Leval, Judging Under the Constitution: Dicta About Dicta, 81 N.Y.U. L. REV. 1249, 1261-63 (2006) (criticizing judicial lawmaking through dicta).

21. See Baker v. Welch, No. 03CIV.2267(JSR)(AJP), 2003 WL 22901051 (S.D.N.Y. Dec. 10, 2003) ("The Court reiterates that this is dicta and is based on the limited record before the Court (and defense counsel's failure to address this issue); other cases with a better developed record may lead to a different result."); Randy Beck, Fueling Controversy, 95 MARQ. L. REV. 735, 743 (2012) [hereinafter Beck, Fueling Controversy] (explaining that since Roe did not require opinion on duration of abortion rights, record not prepared to address factual questions relevant to that issue).

22. Leval, supra note 20, at 1261-62.

23. Beck, Transtemporal Separation of Powers, supra note 15, at 1458-64; Beck, Fueling Controversy, supra note 21, at 738-44; Randy Beck, Self-Conscious Dicta: The Origin of Roe v. Wade's Trimester Framework, 51 AM. J. LegAL HIST. 505, 515 (2011) [hereinafter Beck, Self-Conscious Dicta]; Randy Beck, Gonzales, Casey and the Viability Rule, 103 Nw. U. L. REv. 249 (2009); Randy Beck, The Essential Holding of Casey: Rethinking Viability, 75 UMKC L. REv. 713 (2007) [hereinafter Beck, Essential Holding].

24. Roe v. Wade, 410 U.S. 113, 163 (1973); Doe, 410 U.S. 179, 183-84 (1973).

25. See Roe, 410 U.S. at $163 ;$ Doe, 410 U.S. at $183-84$.

26. See Roe, 410 U.S. at 162-63.

27. Roe v. Wade, Ist Draft (May 18, 1972), in Harry A. Blackmun Papers, Library of Congress, Manuscript Division, Box 151, Folder 4 (on file with the McGeorge Law Review); Doe v. Bolton, 1st Draft (May 25, 1972), in Harry A. Blackmun Papers, Library of Congress, Manuscript Division, Box 152, Folder 7 (on file with the McGeorge Law Review); see also Beck, Self-Conscious Dicta, supra note 23, at 517-18 (discussing the first drafts of Roe and Doe opinions). 
much of the Georgia statute based on an abortion right of unspecified duration. ${ }^{28}$ However, believing the cases warranted a full complement of nine Justices, Justice Blackmun recommended re-argument the following term with Justices Powell and Rehnquist on the bench. ${ }^{29}$ In his memorandum advocating a second round of oral arguments, Justice Blackmun raised a number of questions about how the cases should be approached, including the possibility of employing dicta so the opinions could cover more ground: "Should we spell out-although it would then necessarily be largely dictum-just what aspects are controllable by the State and to what extent?",30

The second draft of Roe began the process of "spell[ing] out" the ramifications of a right to abortion for cases not before the Court, concluding that states would have a compelling interest in regulating abortion after the first trimester of pregnancy. ${ }^{32}$ Justice Blackmun's memorandum accompanying this draft acknowledged that the revised opinion addressed unnecessary issues:

In its present form it contains dictum, but I suspect that in this area some dictum is indicated and not to be avoided.

You will observe that I have concluded that the end of the first trimester is critical. This is arbitrary, but perhaps any other selected point, such as quickening or viability, is equally arbitrary. ${ }^{33}$

Justice Stewart likewise noted the inclusion of dictum in this second draft of Roe, specifically its treatment of the duration of abortion rights:

One of my concerns with your opinion as presently written is the specificity of its dictum-particularly in its fixing of the end of the first trimester as the critical point for valid state action. I appreciate the inevitability and indeed wisdom of dicta in the Court's opinion, but I wonder about the desirability of the dicta being quite so inflexibly "legislative.".

\footnotetext{
28. Beck, Self-Conscious Dicta, supra note 23, at 517-18.

29. Id. at 518 .

30. Id.

31. Id.

32. Id. at 520 .

33. Memorandum from Justice Harry A. Blackmun to the Conference Re: No. 70-18-Roe v. Wade (Nov. 21, 1972), in Harry A. Blackmun Papers, Library of Congress, Manuscript Division, Box 151, Folder 6 (on file with the McGeorge Law Review).

34. Memorandum from Justice Potter Stewart to Justice Harry A. Blackmun Re: Abortion Cases (Dec. 14, 1972), in Harry A. Blackmun Papers, Library of Congress, Manuscript Division, Box 151, Folder 8 (on file with the McGeorge Law Review).
} 
Notwithstanding Justice Stewart's concerns, Roe's dicta arguably became even more "legislative" in the third draft, which formed the basis for the published opinion. ${ }^{35}$ Justice Blackmun drew two distinct durational lines tied to two different state interests, erecting Roe's famous "trimester framework." Court indicated that the state interest in regulating medical aspects of abortion to protect the mother's health would become a compelling interest at the end of the first trimester. ${ }^{37}$ The state interest in protecting the "potential life" of the fetus would not become compelling until the fetus became viable ${ }^{38}$ usually in the third trimester, when the fetus was "potentially able to live outside the mother's womb, albeit with artificial aid."

Roe's unnecessary construction of the trimester framework, including the viability rule, departed from the policy that " $[t]$ he Court will not 'formulate a rule of constitutional law broader than is required by the precise facts to which it is to be applied, ${ }^{, " 40}$ a practice usually viewed as a "safe guide[] to sound judgment. ${ }^{, 41}$ The viability rule-included among other dicta in a case dealing with early abortions $\mathrm{s}^{42}$-prevented state regulation of most second-trimester abortions, at least to the extent that the regulation was premised on a state interest in preserving unborn human life. The Court has never offered a plausible constitutional justification for extending abortion rights to the point of fetal viability ${ }^{43}$ and Roe makes it impossible to adopt abortion laws in line with international norms or with majority sentiment in this country.

35. See Roe v. Wade, 3d Draft (Dec. 21, 1972), in Harry A. Blackmun Papers, Library of Congress, Manuscript Division, Box 151, Folder 6 (on file with the McGeorge Law Review); see also Beck, SelfConscious Dicta, supra note 23, at 525.

36. Roe v. Wade, 410 U.S. 113, 162-63 (1973).

37. Id. at 163 ("With respect to the State's important and legitimate interest in the health of the mother, the 'compelling' point, in the light of present medical knowledge, is at approximately the end of the first trimester.").

38. Id. ("With respect to the State's important and legitimate interest in potential life, the 'compelling' point is at viability.").

39. Id. at 160 . "Viability is usually placed at about seven months ( 28 weeks) but may occur earlier, even at 24 weeks." Id.

40. Ashwander v. Tenn. Valley Auth., 297 U.S. 288, 347 (1936) (Brandeis, J., concurring) (quoting Liverpool, N.Y. \& Phila. S.S. Co. v. Emigration Comm'rs, 113 U.S. 33, 39 (1885)).

41. Liverpool, N.Y. \& Phila. S.S. Co., 113 U.S. at 39.

42. Beck, Self-Conscious Dicta, supra note 23, at 513-15.

43. See Laurence H. Tribe, Foreward: Toward a Model of Rules in the Due Process of Life and Law, 87 HARV. L. REV. 1, 4-5 (1973) ("[E]ven if there is a need to divide pregnancy into several segments with lines that clearly identify the limits of governmental power, 'interest balancing' of the form the Court pursues [in Roe] fails to justify any of the lines actually drawn."). 


\section{A. The Viability Rule Is Arbitrary}

In evaluating whether viability represents a sensible line to distinguish fetuses amenable to state protection from those that are not, it helps to focus on how doctors determine fetal viability. Doctors assess viability in light of biological facts relating to the fetus and technological facts about available medical facilities." In Colautti v. Franklin, the Court emphasized "the uncertainty of the viability determination":

As the record in this case indicates, a physician determines whether or not a fetus is viable after considering a number of variables: the gestational age of the fetus, derived from the reported menstrual history of the woman; fetal weight, based on an inexact estimate of the size and condition of the uterus; the woman's general health and nutrition; the quality of the available medical facilities; and other factors. Because of the number and the imprecision of these variables, the probability of any particular fetus' obtaining meaningful life outside the womb can be determined only with difficulty. Moreover, the record indicates that even if agreement may be reached on the probability of survival, different physicians equate viability with different probabilities of survival, and some physicians refuse to equate viability with any numerical probability at all. In the face of these uncertainties, it is not unlikely that experts will disagree over whether a particular fetus in the second trimester has advanced to the stage of viability. ${ }^{45}$

As Colautti makes clear, rather than being a description of an existing state of facts, the conclusion that a fetus is viable is really more of a medical predictionoften a highly disputable prediction-concerning what might happen to a fetus if you radically change its location. ${ }^{46}$ There is no clear distinguishing feature that separates viable fetuses from previable fetuses. ${ }^{47}$ Different doctors might classify the same fetus as viable or nonviable, perhaps for reasons having nothing to do with the fetus itself, but arising instead from differences in medical skill or treatment philosophy. ${ }^{48}$

The viability rule purported to balance the state interest in protecting fetal life against the interests of a woman in terminating a pregnancy. ${ }^{49}$ It identified a

44. See Colautti v. Franklin, 439 U.S. 379, 395-96 (1979).

45. Id.

46. See id.

47. See id.

48. Beck, Gonzales, Casey and the Viability Rule, supra note 23, at 260. Research indicates that the medical team's assessment of viability itself influences prospects for survival. $I d$. This would make sense if viability determinations guide decision making concerning how aggressively to treat preterm infants.

49. See Roe v. Wade, 410 U.S. 113, 162-63 (1973). 
tipping point, at which the state interest in fetal life-an interest which, the Court stated, "grows in substantiality as the woman approaches term"-could be thought to outweigh the mother's interests. ${ }^{50}$ Presumably, the Roe Court's identification of viability as that tipping point rested on a view that the fetus either becomes more valuable to the state in some constitutionally relevant sense when it might be able to survive outside the womb, or that the mother's interest in ending pregnancy becomes less weighty at that point. Regrettably, the Roe Court did not clarify the reasoning underlying its conclusion. ${ }^{51}$ While the Court alluded to "logical and biological justifications" for "State regulation protective of fetal life after viability," ${ }^{, 2}$ it nowhere explained those justifications or why they took on added weight at the point when the fetus crossed the viability threshold. ${ }^{53}$ Many states would take the position that the interest in protecting unborn human life weighs just as heavily in the weeks and days before doctors deem the fetus viable as in the days and weeks afterwards. A number of Justices have therefore described viability as an arbitrary line. ${ }^{54}$ Indeed, even Justice Blackmun acknowledged privately to his colleagues that drawing a line at the first trimester or at viability might be "equally arbitrary.",5s

Viability represents an arbitrary line because factors that may influence viability are "morally and constitutionally irrelevant." neonatal care, the state may be able to protect a fetus from abortion today when, just a few years before, it would have been constitutionally disabled from

50. Id.

51. See id.

52. Id. at 163.

53. See Roe, 410 U.S. 113.

54. See, e.g., Planned Parenthood of Se. Pa. v. Casey, 505 U.S. 833, 989 n.5 (1992) (Scalia, J., joined by Rehnquist, C.J., and Thomas, J., concurring in the judgment in part and dissenting in part) ("The arbitrariness of the viability line is confirmed by the Court's inability to offer any justification for it beyond the conclusory assertion that it is only at that point that the unborn child's life 'can in reason and all fairness' be thought to override the interests of the mother."); Thornburgh v. Am. Coll. of Obstetricians \& Gynecologists, 476 U.S. 747, 795 (1986) (White, J., joined by Rehnquist, J., dissenting).

The governmental interest at issue is in protecting those who will be citizens if their lives are not ended in the womb. The substantiality of this interest is in no way dependent on the probability that the fetus may be capable of surviving outside the womb at any given point in its development, as the possibility of fetal survival is contingent on the state of medical practice and technology, factors that are in essence morally and constitutionally irrelevant. The State's interest is in the fetus as an entity in itself, and the character of this entity does not change at the point of viability under conventional medical wisdom.

Id.; see also, e.g., City of Akron v. Akron Ctr. for Reprod. Health, 462 U.S. 416, 461 (1983) (O'Connor, J., joined by White, J., and Rehnquist, J., dissenting) ("The choice of viability as the point at which the state interest in potential life becomes compelling is no less arbitrary than choosing any point before viability or any point afterward.").

55. Beck, Self-Conscious Dicta, supra note 23, at 516-18; see also supra text accompanying note 33.

56. Thornburgh, 476 U.S. at 795 (White, J., dissenting). 
protecting an identical fetus. ${ }^{57}$ A mother in an urban area with advanced neonatal facilities may have a viable fetus that might then become nonviable at a later date if the mother travels to a remote location with more primitive treatment options. ${ }^{58}$ Even more troubling is evidence that viability varies based on biological factors such as race and gender. ${ }^{59}$ African-American and female fetuses tend to reach viability at an earlier gestational age than their Caucasian and male counterparts. $^{60}$ As a result, the right to abortion tends to last longer for Caucasian women than for similarly situated African-American women. ${ }^{61}$

Behavioral and environmental factors can also influence the viability threshold. For instance, research has shown that smoking during pregnancy slows fetal growth. ${ }^{6}$ Since fetal weight strongly influences viability, women who smoke during pregnancy can expect the right to abortion under the viability rule to last longer than for similarly situated women who do not. Indeed, even altitude has a measurable impact on fetal growth and, hence, viability:

On average, every 3,300 feet of elevation gained reduces fetal weight by about 3.5 ounces, according to a 1997 study in Colorado.

So in Summit County, with an average elevation of about 9,000 feet, babies could on average be born about 10 ounces lighter than those born at sea level.

The percentage of low birth weight infants increases by around 50 percent from the lowest elevations to the highest elevations in the state, the study showed. ${ }^{63}$

57. Beck, Gonzales, Casey and the Viability Rule, supra note 23, at 258-59.

58. Id. at 259 (quoting STEPHEN COLEMAN, THE ETHICS OF ARTIFICIAL UTERUSES: IMPLICATIONS FOR REPRODUCTION AND ABORTION 87 (2004)).

59. See id. at 260-61; Beck, Essential Holding, supra note 23, at 731.

60. Id.

61. Beck, Gonzales, Casey and the Viability Rule, supra note 23, at 261.

62. U.S. DeP'T OF Health \& Human SERvS., THE Health CONSEQuences of Smoking: A RePort of THE SURGEON GENERAL 576 (2004), available at http://www.cdc.gov/tobacco/data_statistics/sgr/2004/ complete_report/index.htm (on file with the McGeorge Law Review) ("The evidence is sufficient to infer a causal relationship between maternal active smoking and fetal growth restriction and low birth weight."); U.S. DeP'T OF Health \& Human Servs., The 2004 Surgeon General's Report, The Health Consequences OF SMOKING: WHAT IT MEANS TO YOU 18 (2004), available at http://www.thriveri.org/documents/ $4 \mathrm{~g}$ _health_consequences_smoking.pdf (on file with the McGeorge Law Review) ("Babies of mothers who smoked during pregnancy have lower birth weights, often weighing less than 5.5 pounds. Low birth weight babies are at greater risk for childhood and adult illnesses and even death. Babies of smokers have less muscle mass and more fat than babies of nonsmokers. Nicotine causes the blood vessels to constrict in the umbilical cord and womb. This decreases the amount of oxygen to the unborn baby. This can lead to low birth weight.").

63. Julia Conors, The Altitude Efffect [sic], Summit DaILY NEws (Aug. 7, 2007), http://www. summitdaily.com/article/20070807/NEWS/70807025 (on file with the McGeorge Law Review); see also Gwenn M. Jensen \& Lorna G. Moore, The Effect of High Altitude and Other Risk Factors on Birthweight: Independent 


\section{3 / State Interests and the Duration of Abortion Rights}

Other factors being equal, therefore, one would expect the right to abortion under the viability rule to last longer on average for women living in the mountains of Colorado than for similarly situated women living on the California coast.

The basic problem with the viability rule is that the Roe Court unreflectively imported a medical line into an unrelated constitutional context. A student's time running the one-hundred yard dash may be significant to the track coach, but should have no impact on grades awarded by the math teacher. Similarly, the fact that fetal viability may be significant to doctors considering treatment options for pregnant women does not show that it should be significant to judges determining the constitutional status of a fetus. Doctors determining viability make the best predictions they can about fetal survival in light of the particular circumstances and the available data. The statistical conclusion that an AfricanAmerican or female fetus may be more likely to survive premature delivery than a Caucasian or male fetus is just a fact ${ }^{64}$ and, in the medical context, does not purport to say anything about the worth or significance of different fetuses. The medical scenarios that lead doctors to focus on fetal viability have little to do with the duration of abortion rights, where the focus is on the value a state may attribute to the developing fetus from a moral or constitutional perspective. Given that crossing the viability threshold does not involve any significant change in the fetus that suddenly makes it more valuable in light of the state interest in protecting human life, and given that the viable fetus imposes no less of a burden on its mother than a previable fetus, it is hard to see why the Court views this medically significant line as controlling amenability to state protection as a matter of constitutional law.

\section{B. The Viability Rule Is Extreme}

The viability rule is not only arbitrary, but also extreme. One line of evidence derives from comparing the viability rule with the abortion laws of other countries. In certain contexts, Justice Kennedy has been receptive to this sort of international comparison. For instance, in Roper v. Simmons, resolving an Eighth Amendment issue, Justice Kennedy found that, though international practice is not controlling, the Court's "determination that the death penalty is disproportionate punishment for offenders under 18 finds confirmation in the stark reality that the United States is the only country in the world that continues to give official sanction to the juvenile death penalty." ${ }^{.65}$ With respect to abortion, the United States is one of only six countries that permit abortion for any reason

or Interactive Effects?, 87 AM. J. PUB. HEALTH 1003, 1003 (1997).

64. See supra notes $60-61$ and accompanying text.

65. 542 U.S. 551,575 (2005); see also Lawrence v. Texas, 539 U.S. 558, 573 (2003) (citing decision of European Court of Human Rights in discussing due process issues raised by state statute criminalizing homosexual conduct). 
to the point of viability or beyond. ${ }^{66}$ Most nations require a legally permissible reason for seeking an abortion. ${ }^{67}$ Of the minority of countries that allow abortion for any reason, the great majority recognize the right only through the first twelve weeks of pregnancy. ${ }^{68}$

The second line of evidence showing that the viability rule is extreme rests on polling data in this country. In July of 1996, a sizable majority of the publicsixty-four percent-said they believed abortion should generally be legal in the first three months of pregnancy, compared to thirty percent who said abortion should generally be illegal during that period. ${ }^{69}$ However, an enormous shift in opinion occurred when Gallup asked about second-trimester abortions. ${ }^{70}$ An even larger majority of sixty-five percent said that abortion should be generally illegal in the second trimester, compared to only twenty-six percent who thought it should generally be legal at that stage. ${ }^{71}$ Fifteen years later, the percentage of the public opposing second-trimester abortions had increased. ${ }^{22}$ A Gallup poll in June 2011 found a sixty-two to thirty-five percent split between those who thought abortion should generally be legal in the first trimester and those who thought it should generally be illegal. ${ }^{73}$ But, when asked about the second trimester, seventy-one percent said abortion should generally be illegal compared to only twenty-four percent who thought it should generally be legal at that stage. ${ }^{74}$

As these numbers suggest, many people in the United States support legal access to abortion in the first trimester of pregnancy, but not in the second trimester. ${ }^{75}$ In another recent Gallup poll, over half of those who identified themselves as "pro-choice" told pollsters that abortion should be illegal in the second trimester. ${ }^{76}$ Nevertheless, as a result of the Supreme Court's viability rule, second-trimester abortions remain presumptively legal, notwithstanding supermajority public opinion to the contrary.

66. Beck, Gonzales, Casey and the Viability Rule, supra note 23, at 264.

67. Id. at 263-64.

68. Id. at 264 .

69. See Abortion, GALluP, http://www.gallup.com/poll/1576/Abortion.aspx (last visited Mar. 12, 2012) (on file with the McGeorge Law Review) (summarizing prior polling on abortion questions).

70. See id.

71. Id.

72. See id.

73. Id.

74. Id.

75. See Beck, Fueling Controversy, supra note 21, at 746-47.

76. Lydia Saad, Plenty of Common Ground Found in Abortion Debate, Gallup (Aug. 8, 2011), http://www.gallup.com/poll/148880/plenty-common-ground-found-abortion-debate.aspx (on file with the McGeorge Law Review) (reporting that fifty-two percent of self-described "pro-choice" respondents and ninety percent of "pro-life" respondents support a policy of making "[a]bortion illegal in second trimester"). 


\section{JUSTICE KENNEDY AND THE VIABILITY RULE}

Justice Kennedy has joined or written a number of opinions in which Roe's viability rule played a role, but it is not clear whether those opinions reflect any final, settled view on the duration of abortion rights. In Webster $v$. Reproductive Health Services, Justice Kennedy first joined a plurality opinion criticizing viability as a constitutionally controlling line in the Court's abortion jurisprudence. ${ }^{77}$ He took a somewhat different position when he jointly authored a plurality opinion in Planned Parenthood of Southeastern Pennsylvania v. Casey, purporting to reaffirm the viability rule. ${ }^{78}$ However, since Casey involved regulations applicable from the outset of pregnancy, the plurality's discussion of the duration of abortion rights constituted dictum, with no impact on the pending litigation. $^{79}$ The Casey plurality, while purporting to reaffirm the viability rule, greatly diminished the significance of viability for constitutional analysis, permitting previability regulations that Roe would not have allowed. ${ }^{80}$

More recently, in his dissenting opinion in Stenberg v. Carhart and his majority opinion in Gonzales $v$. Carhart, Justice Kennedy voted to uphold regulations of late-term abortions that applied both previability and postviability. ${ }^{81}$ Justice Kennedy expressed concern with the methods used to perform second-trimester abortions and proved willing to accept a broadened array of state interests offered as justifications for the regulations in question. ${ }^{82}$ In particular, he approved a state interest in distinguishing abortion from infanticide that implicitly analogized the previable fetus to a newborn infant. ${ }^{83}$ While it is possible Justice Kennedy may continue to adhere to the viability rule in future litigation, his opinions highlight multiple routes by which he might recognize greater state authority to regulate abortions after the first trimester. ${ }^{84}$

\section{A. Webster v. Reproductive Health Services}

Justice Kennedy first weighed in on Roe's viability rule after just one year on the Supreme Court. In Webster v. Reproductive Health Services, a fractured majority upheld several challenged provisions of a Missouri abortion statute. ${ }^{85}$

77. 492 U.S. 490 (1989); see also infra Part III.A.

78. 505 U.S. 833, 870 (1992) (O'Connor, Kennedy \& Souter, JJ., plurality).

79. See id. at 844-46, 870-74.

80. See infra Part III.B.

81. Gonzales v. Carhart, 550 U.S. 124 (2007); Stenberg v. Carhart, 530 U.S. 914, 956 (2000) (Kennedy, J., joined by Rehnquist, C.J., dissenting).

82. See Gonzales, 550 U.S. 124; Stenberg, 530 U.S. at 956.

83. See infra Parts III.C-D.

84. See infra Part III.E.

85. 492 U.S. 490 (1989). 
Justice Kennedy and Justice White joined Chief Justice Rehnquist's plurality opinion, while Justices O'Connor and Scalia each concurred separately. ${ }^{86}$ The most controversial provision of the statute concerned medical determinations of viability; the plurality characterized the statute as creating "a presumption of viability at 20 weeks, which the physician must rebut with tests indicating that the fetus is not viable prior to performing an abortion." direct[ed] the physician's determination as to viability by specifying consideration, if feasible, of gestational age, fetal weight, and lung capacity.",88 However, the plurality rejected a reading of the statute that would require performing certain tests, even if unhelpful in determining the viability of a particular fetus. ${ }^{89}$

The Webster plurality considered the Missouri statute inconsistent with the viability rule as developed in the Supreme Court's post-Roe case law. ${ }^{00}$ The plurality thought the statute incompatible with the Court's conclusion in Planned Parenthood of Central Missouri v. Danforth that " "the determination of whether a particular fetus is viable is, and must be, a matter for the judgment of the responsible attending physician."'91 More particularly, the statute ran afoul of the extension of Danforth's principle in Colautti, where the Court said that "neither the legislature nor the courts may proclaim one of the elements entering into the ascertainment of viability - be it weeks of gestation or fetal weight or any other single factor-as the determinant of when the State has a compelling interest in the life or health of the fetus."

This conflict between the Missouri statute and the Court's earlier decisions led the Webster plurality to critique Roe's "rigid trimester analysis of the course of a pregnancy" for "making constitutional law in this area a virtual Procrustean bed." ${ }^{, 93}$ The plurality noted that "[t]he key elements of the Roe frameworktrimesters and viability - are not found in the text of the Constitution or in any place else one would expect to find a constitutional principle. ${ }^{\prime 4}$ The opinion pointedly challenged the central premise of the viability rule concerning the value of developing human life:

[W]e do not see why the State's interest in protecting potential human life should come into existence only at the point of viability, and that

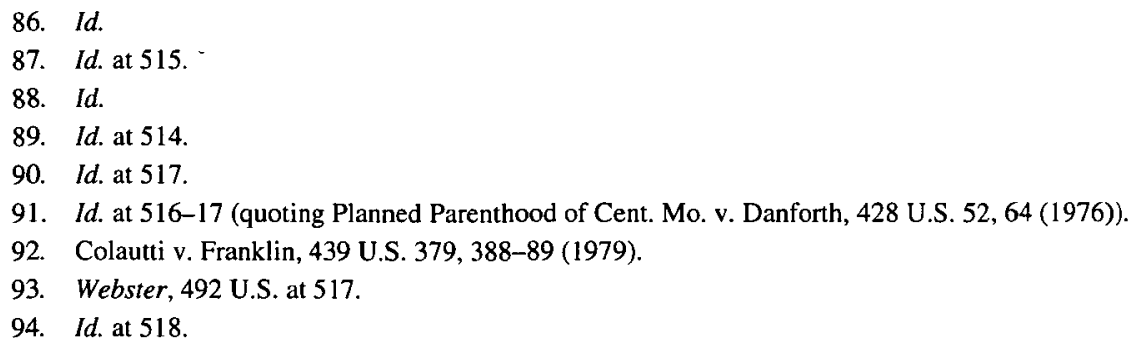

94. Id. at 518. 


\section{3 / State Interests and the Duration of Abortion Rights}

there should therefore be a rigid line allowing state regulation after viability but prohibiting it before viability. The dissenters in Thornburgh, writing in the context of the Roe trimester analysis, would have recognized this fact by positing against the "fundamental right" recognized in Roe the State's "compelling interest" in protecting potential human life throughout pregnancy. "[T]he State's interest, if compelling after viability, is equally compelling before viability." 95

Even though the Missouri viability determination statute increased the cost of abortions and was irreconcilable with prior precedent applying the viability rule, the plurality found the statute constitutional on the ground that it "permissibly furthers the State's interest in protecting potential human life . . .,"96

\section{B. Planned Parenthood of Southeastern Pennsylvania v. Casey}

In Planned Parenthood of Southeastern Pennsylvania v. Casey, Justices Kennedy, O'Connor, and Souter jointly authored a plurality opinion that reaffirmed the "essential holding of Roe v. Wade." The plurality sought to retain the basic right to abortion, in part because "people have organized intimate relationships and made choices that define their views of themselves and their places in society, in reliance on the availability of abortion in the event that contraception should fail." ${ }^{.98}$ With respect to the duration of abortion rights, the plurality opined that viability should remain a constitutionally determinative dividing line in pregnancy: "Before viability, the State's interests are not strong enough to support a prohibition of abortion or the imposition of a substantial obstacle to the woman's effective right to elect the procedure."99 At the same time, the plurality recognized that "the State has legitimate interests from the outset of the pregnancy in protecting the health of the woman and the life of the fetus that may become a child."100 Therefore, the opinion discarded Roe's trimester framework, ${ }^{101}$ and permitted previability abortion regulations designed

95. Id. at 519 (quoting Thornburgh v. Am. Coll. of Obstetricians \& Gynecologists, 476 U.S. 747, 795 (1986) (White, J., dissenting)).

96. Id. at 519-20. Justice O'Connor concurred on the ground that the Missouri statute, when properly read, did not conflict with Roe and subsequent cases. Id. at 525 (O'Connor, J., concurring). Justice Scalia argued that the plurality opinion would "effectively" overrule Roe, something he would prefer to do "more explicitly." Id. at 532 (Scalia, J., concurring).

97. 505 U.S. 841, 846 (1992) (O'Connor, Kennedy, \& Souter, JJ., plurality).

98. Id. at 856 .

99. Id. at 846 .

100. Id.

101. Id. at 873 . 
to protect fetal life, so long as the regulations did not create an "undue burden" on abortion rights prior to viability. ${ }^{102}$

In some respects, the Justices in the Casey plurality seemed to desire a peacemaking role in the abortion controversy. ${ }^{103}$ Their opinion took account of the interests driving the abortion conflict and allowed activists on either end of the spectrum to walk away with a partial victory addressing some of their concerns. The opinion gave pro-life citizens somewhat greater leeway to pursue abortion regulation through the legislative process and recognized a legitimate state interest in protecting fetal life from the outset of pregnancy. At the same time, the opinion assured pro-choice citizens that the ultimate decision about abortions early in pregnancy would be made by the pregnant woman. However, it is difficult for judges to play a mediating role when issuing authoritative opinions. A true mediator can discuss possible compromises with contending parties, adjust proposals as the parties reveal more about their underlying concerns, and then lobby the parties to voluntarily accept an arrangement calculated to resolve the conflict. A judicial opinion, on the other hand, affords no opportunity for contending parties to discuss a proposed resolution and explain vital issues it overlooks. Since the Casey Court had no reason to focus on late-term abortions, the settlement fashioned by the plurality failed to account for some of the central concerns motivating pro-life activism, especially the unique issues surrounding second-trimester abortions.

Casey did relieve some of the pressure that had built up around the abortion controversy, partially remanding the issue to the legislatures where contending parties can hash out contentious issues. However, the dicta purporting to reaffirm the viability rule limited the potential for legislative mediation of the abortion conflict. ${ }^{104}$ Given that approximately seventy percent of Americans believe abortion should generally be illegal in the second trimester of pregnancy, ${ }^{105}$ a rule that prevents legislators from placing any "substantial obstacle" in the path of a second-trimester abortion impedes legislative attempts to work out compromises acceptable to a majority of the public.

The Casey plurality's decision to retain the viability rule represented dictum for the same reason that creation of the viability rule was dictum in Roe. ${ }^{106}$ The provisions of the Pennsylvania statute before the Court in Casey-its definition of a "medical emergency," the informed consent provision, the twenty-four hour

102. Id. at 874 .

103. See id. at 867 (discussing the "dimension present whenever the Court's interpretation of the Constitution calls the contending sides of a national controversy to end their national division by accepting a common mandate rooted in the Constitution").

104. See generally Beck, Fueling Controversy, supra note 23, at $744-49$ (discussing how the viability rule hinders political resolution of the abortion controversy).

105. See supra text accompanying note 74 .

106. See supra text accompanying notes $20-43$. 
waiting period, the spousal-notification provision, the parental-consent requirement, and the recordkeeping and reporting rules-all applied to abortions performed early in pregnancy. ${ }^{107}$ The validity of these provisions did not turn on the duration of abortion rights. ${ }^{108}$ Therefore, the parties' briefs focused on whether the Court should continue to recognize a constitutional right to an abortion rather than the distinct question of how late in pregnancy such a right should endure. ${ }^{109}$ Nothing in the case forced the Court to confront the unique and troubling issues raised by late-term abortions as distinct from early abortions. ${ }^{10}$

The Casey plurality premised its reaffirmation of the viability rule (in diluted form) on stare decisis considerations." The plurality acknowledged an obligation to justify the viability rule: "[L]egislatures may draw lines which appear arbitrary without the necessity of offering a justification. But courts may not. We must justify the lines we draw."112 However, the plurality's justification for the viability rule essentially boiled down to a single sentence:

[T] he concept of viability, as we noted in Roe, is the time at which there is a realistic possibility of maintaining and nourishing a life outside the womb, so that the independent existence of the second life can in reason and all fairness be the object of state protection that now overrides the rights of the woman. ${ }^{113}$

This suggestion that viability marks the "independent existence" of a "second life" must be harmonized with the plurality's conclusion that a state has a legitimate interest in protecting "the life of the fetus that may become a child" beginning from "the outset of the pregnancy."114 Justice Kennedy would later write in Gonzales, "by common understanding and scientific terminology, a fetus is a living organism while within the womb, whether or not it is viable outside

107. Beck, Essential Holding, supra note 23, at 716-17.

108. See id.

109. Id. at 718 .

110. See Part II.C-D (discussing the right to abortion in the context of second-trimester methods in Stenberg and Gonzales).

111. Planned Parenthood of Se. Pa. v. Casey, 505 U.S. 841, 870 (1992).

112. Id.

113. Id. The plurality also argued that no line is "more workable" than viability. Id. I question this assertion below, since a line based on gestational age would avoid some of the problems and ambiguities associated with the viability rule. See infra notes 198-200 and accompanying text. In any event, even if viability worked as well as other possible lines, that does not provide a reason for selecting viability as the controlling point in pregnancy. See Beck, Gonzales, Casey and the Viability Rule, supra note 23, at 273 . The plurality also argued that a woman who fails to obtain an abortion before viability could be said to have consented to state regulation. Casey, 505 U.S. at 870 . But, one could make the same argument about other points in pregnancy, so this contention does not justify selecting viability over other possible lines. See Beck, Gonzales, Casey and the Viability Rule, supra note 23, at 273.

114. Casey, 505 U.S. at 846. 
the womb." 115 Thus, one cannot understand the plurality as denying that a fetus is a life distinct from the mother before viability.

The plurality's somewhat understated justification for the viability rule ${ }^{116}$ presumably means that the hypothetical "independent existence" associated with viability somehow makes the fetus more valuable or worthy of state protection than the same fetus immediately before it crosses the viability threshold. This position raises a number of questions about how the plurality viewed the interplay of "state power and fetal entitlement." "In an important sense, the viable fetus is no more independent of the mother than the previable fetus; both remain in the womb and depend on the mother's body for survival. There is no other difference in kind between the previable and the viable fetus, such as a clear distinction in attributes. The only difference between the previable and the viable fetus is a debatable and possibly inaccurate prediction, made by a fallible and possibly self-interested doctor, about the probable consequences of removing the fetus from the womb. ${ }^{118}$

Though they did not have the luxury of writing on a blank slate, the Casey plurality, like the Justices in Roe, might have done well to forego opining on the duration of abortion rights until the Court faced a case where the answer mattered to the outcome. Early abortions and late-term abortions involve distinct procedures and raise different issues. In reaffirming Roe's conclusion "that the Constitution protects a woman's right to terminate her pregnancy in its early stages," " Casey could have left unaddressed the effect of that reaffirmation on late-term abortions, which the challenged provisions of the Pennsylvania statute did not specifically implicate.

If the Casey Court had waited for a case involving late-term abortions, it would have enjoyed the benefit of briefing and a factual record focused on the duration of abortion rights. The Court could have addressed the durational question in the context of a concrete controversy, where the consequences of drawing a particular line would be starkly highlighted. Having been reminded of Colautti's emphasis on "the uncertainty of the viability determination," 120 Casey plurality might have been less apt to embrace viability on the theory that it would provide "a line that is clear" to govern abortion rights. ${ }^{121}$ Having been reminded that Roe literally did not provide any reason for adopting the viability

115. Gonzales v. Carhart, 550 U.S. 124, 147 (2007).

116. Casey, 505 U.S. at 989 n.5 (Scalia, J., concurring in part and dissenting in part) (describing plurality's argument as "conclusory").

117. Beck, Gonzales, Casey and the Viability Rule, supra note 23, at 275-76.

118. See supra notes $45-48$ and accompanying text.

119. Casey, 505 U.S. at 844.

120. Colautti v. Franklin, 439 U.S. 379, 395 (1979).

121. Casey, 505 U.S. at 869 . 
rule, ${ }^{122}$ the plurality might have avoided describing Roe's line-drawing effort as "a reasoned statement, elaborated with great care." 123 If the Court had waited for a case with plenary briefing and argument on the duration of abortion rights, it is less likely the plurality would have written that "no line other than viability ... is more workable." 124 After all, a line based on a particular gestational age (for example, twenty weeks) is simpler, less debatable, and easier to apply than viability, which incorporates gestational age among several factors influencing a disputable and semi-subjective medical prediction. ${ }^{125}$ In a case with plenary briefing, where the duration of abortion rights affected the outcome of the litigation, the Court could have carefully weighed the evidence that viability varies with fetal race and gender, as well as behavioral and environmental factors like maternal smoking and altitude. ${ }^{126}$

At the same time, it is important to recognize that the Casey plurality attempted to steer a careful course in a high-profile case. ${ }^{127}$ It is easy to sit back with the benefit of twenty years' hindsight and suggest what the plurality should have done differently, but the plurality had to act quickly in the heat of intense public scrutiny. In any event, it is worth noting that, although the plurality purported to retain the viability rule, it did so in a much-diminished form. Considered against the background of prior case law, Casey is a substantial retreat from Roe with respect to the legal significance attributed to fetal viability. Viability no longer marked the point in pregnancy at which states could regulate to protect fetal life, but now merely represented the point at which those regulations could take the form of an outright prohibition. ${ }^{128}$ While reaffirming the viability rule in dicta, the Casey plurality substantially weakened the rule, making it less significant than the version applied after Roe.

\section{Stenberg v. Carhart}

Stenberg v. Carhart, the first "partial-birth abortion" case to make its way to the Supreme Court, shone a judicial spotlight on late-term methods of abortion. ${ }^{129}$ In defending its statute, Nebraska did not challenge the Casey plurality's controlling opinion. ${ }^{130}$ Consequently, the case offered no opportunity for

\footnotetext{
122. See Beck, Gonzales, Casey and the Viability Rule, supra note 23, at 268-70.

123. Casey, 505 U.S. at 870.

124. Id.

125. See supra text accompanying note 45 .

126. See supra notes $60-63$ and accompanying text.

127. See Casey, 505 U.S. 833.

128. See id. at 873 (rejecting Roe's trimester framework).

129. See 530 U.S. 914 (2000).

130. Id. at $930-31$.
} 
reconsideration of the viability rule. ${ }^{131}$ The Court grappled with the distinction between the method of abortion Nebraska purported to forbid, the "dilation and extraction" (D\&X) method, in which the fetus is killed after partial delivery, and the more common "dilation and evacuation" (D\&E) method, in which the fetus is dismembered and removed from the womb piece by piece. ${ }^{132}$ A $5-4$ majority struck down the Nebraska statute on two grounds: the statute (1) did not contain an exception for a case where the doctor might view the $D \& X$ as preferable to protect the mother's health; and (2) could be read to forbid both D\&X and D\&E abortions, ${ }^{133}$ which Nebraska conceded would amount to an undue burden on abortion rights. ${ }^{134}$

Justice Kennedy wrote a dissenting opinion in Stenberg. ${ }^{135}$ His opinion made clear that he found the methods used to perform late-term abortions troubling. ${ }^{136}$ He also agreed with the majority's acknowledgement that the descriptions of the $D \& X$ and D\&E in the majority opinion might seem "clinically cold or callous','137:

The majority views the procedures from the perspective of the abortionist, rather than from the perspective of a society shocked when confronted with a new method of ending human life. Words invoked by the majority, such as "transcervical procedures," "[o]smotic dilators," "instrumental disarticulation," and "paracervical block," may be accurate and are to some extent necessary; but for citizens who seek to know why laws on this subject have been enacted across the Nation, the words are insufficient. Repeated references to sources understandable only to a trained physician may obscure matters for persons not trained in medical terminology. ${ }^{138}$

Justice Kennedy went on to describe both methods of late-term abortion at issue in the case using clear, sometimes even chilling, language. ${ }^{139}$

Apart from his apparent aversion to late-term methods of abortion, Justice Kennedy's principal difference with the majority concerned how Casey should be

131. See id.

132. Id. at $923-30$.

133. Id. at 930,939 .

134. See id. at 949 (O'Connor, J., concurring) ("Nebraska conceded at oral argument that 'the State could not prohibit the D\&E procedure."').

135. Id. at $956-79$.

136. See id. at 957.

137. Id. at 957 (Kennedy, J., dissenting) (quoting the majority opinion, id. at 923).

138. Id. at $957-58$ (citations omitted).

139. Id. at $958-60$. 
understood with respect to the role of state interests in evaluating abortion regulations. ${ }^{140}$

As [Dr. Carhart] interprets the controlling cases in this Court, the only two interests the State may advance through regulation of abortion are in the health of the woman who is considering the procedure and in the life of the fetus she carries. The Court, as I read its opinion, accedes to his views, misunderstanding Casey and the authorities it confirmed.

Casey held that cases decided in the wake of Roe v. Wade had "given [state interests] too little acknowledgment and implementation." The decision turned aside any contention that a person has the "right to decide whether to have an abortion without interference from the State," and rejected a strict scrutiny standard of review as "incompatible with the recognition that there is a substantial state interest in potential life throughout pregnancy. The very notion that the State has a substantial interest in potential life leads to the conclusion that not all regulations must be deemed unwarranted." We held it was inappropriate for the Judicial Branch to provide an exhaustive list of state interests implicated by abortion.

Casey is premised on the States having an important constitutional role in defining their interests in the abortion debate. It is only with this principle in mind that Nebraska's interests can be given proper weight. The State's brief describes its interests as including concern for the life of the unborn and "for the partially-born," in preserving the integrity of the medical profession, and in "erecting a barrier to infanticide." A review of Casey demonstrates the legitimacy of these policies. The Court should say so. ${ }^{141}$

In his Stenberg dissent, Justice Kennedy recognized the important role state legislatures play in mediating societal divisions over abortion. ${ }^{142} \mathrm{He}$ argued that the Court should not foreclose state "political processes" from regulating "to promote the life of the unborn and to ensure respect for all human life and its potential." ${ }^{143}$ State legislative deliberations represent "a vital means for citizens to address these grave and serious issues," a necessary step for progress "in the attainment of some degree of consensus."

140. See id. at $960-61$.

141. Id. at $960-61$ (second alteration in original) (citations omitted).

142. Id. at $968-70$ (noting that "legislators have been afforded the widest latitude" in situations where there is "disagreement[] among medical professionals").

143. Id. at 957 .

144. Id. 
In discussing the state interests furthered by the Nebraska statute, Justice Kennedy affirmed that "[s]tates may take sides in the abortion debate and come down on the side of life, even life in the unborn." focused on a number of state concerns that seem distinct from the bare interest in protecting "potential life" that the Court permitted states to pursue in Roe.$^{146}$ For instance, he argued that "[s]tates also have an interest in forbidding medical procedures which, in the State's reasonable determination, might cause the medical profession or society as a whole to become insensitive, even disdainful, to life, including life in the human fetus." ${ }^{147}$ Here, the concern was not the moral question of the value of fetal life per se, but rather a sociological concern about the effects of a disturbing method of late-term abortion on public and medical attitudes regarding human life. ${ }^{148}$ Similarly, he thought the Nebraska statute furthered a state interest in protecting the reputation of the medical profession: "A State may take measures to ensure the medical profession and its members are viewed as healers, sustained by a compassionate and rigorous ethic and cognizant of the dignity and value of human life, even life which cannot survive without the assistance of others." ${ }^{\text {"19 }}$ Justice Kennedy also focused on the partial delivery of the fetus in the course of a D\&X abortion, which made the procedure more akin to infanticide than the D\&E procedure:

Nebraska was entitled to find the existence of a consequential moral difference between the procedures. We are referred to substantial medical authority that $\mathrm{D} \& \mathrm{X}$ perverts the natural birth process to a greater degree than D\&E, commandeering the live birth process until the skull is pierced. ... The D\&X differs from the D\&E because in the D\&X the fetus is "killed outside of the womb" where the fetus has "an autonomy which separates it from the right of the woman to choose treatments for her own body." Witnesses to the procedure relate that the fingers and feet of the fetus are moving prior to the piercing of the skull; when the scissors are inserted in the back of the head, the fetus' body, wholly outside the woman's body and alive, reacts as though startled and goes limp. D\&X's stronger resemblance to infanticide means Nebraska could conclude the procedure presents a greater risk of disrespect for life and a

145. Id. at 961 .

146. See infra text accompanying notes $147-50$ (discussing the states' sociological interests and interest in protecting the medical profession).

147. Stenberg, 530 U.S. at 961 (Kennedy, J., dissenting).

148. See id.

149. Id. at 962 . 


\section{3 / State Interests and the Duration of Abortion Rights}

consequent greater risk to the profession and society, which depend for

their sustenance upon reciprocal recognition of dignity and respect. ${ }^{150}$

This resemblance between the D\&X abortion and infanticide underlies Justice Kennedy's response to two of the concurring Justices, who argued that $D \& X$ and D\&E methods of abortion are both gruesome, making it irrational to ban one and permit the other. ${ }^{151}$

\section{Gonzales v. Carhart}

After the Court invalidated Nebraska's partial-birth abortion statute in Stenberg, Congress passed federal legislation prohibiting the procedure. ${ }^{152}$ The Supreme Court upheld this federal law in Gonzales v. Carhart, with Justice Kennedy writing the 5-4 majority opinion. ${ }^{153}$ Justice Kennedy's opinion found the federal statute more specific in describing the $D \& X$ procedure (this time labeled an "intact dilation and evacuation," or an intact D\&E) than the Nebraska statute in Stenberg, eliminating the concern that the statute might also be read to forbid standard D\&E abortions. ${ }^{154}$ The majority also accepted the congressional judgment that a maternal-health exception was not needed because the intact D\&E is never necessary to preserve maternal health. ${ }^{155}$

The Gonzales opinion applied the standards from the Casey plurality, including its dicta on viability, even though not all of the Justices in the majority had agreed with Casey. ${ }^{156}$ Gonzales introduced Casey's standards with the statement "[w]e assume the following principles for the purposes of this opinion," 157 as if the majority was saving for another day the question of whether the Casey plurality opinion should continue to control. Justice Kennedy's opinion later referenced "the principles accepted as controlling here," impression that the majority might not be fully committed to Casey as a final statement of the Court's position on abortion rights.

Justice Kennedy noted the federal ban on partial-birth abortion applied "both previability and postviability because, by common understanding and scientific terminology, a fetus is a living organism while within the womb, whether or not

150. Id. at $962-63$ (emphasis in original).

151. Id. (Justice Kennedy responding to Justices Stevens and Ginsburg).

152. Partial-Birth Abortion Ban Act of 2003, 18 U.S.C. $\S 1531$ (2006).

153. 550 U.S. 124 (2007).

154. Id. at $150-56$.

155. Id. at $161-67$.

156. Id. at 145 .

157. Id. at 146 .

158. Id. at 156. 
it is viable outside the womb." 159 Despite the statute's application prior to fetal viability, Gonzales upheld the legislation on the theory that it did not place any undue burden on previability abortions. ${ }^{160}$

As in his Stenberg dissent, Justice Kennedy's Gonzales opinion focused on governmental interests furthered by the federal statute, some of which seemed to go beyond Roe's bare interest in protecting "potential life."161 The majority credited a congressional finding that allowing partial-birth abortion would "further coarsen society to the humanity of not only newborns, but all vulnerable and innocent human life," 162 just as Justice Kennedy in Stenberg had accepted Nebraska's argument that the procedure could cause "society as a whole to become insensitive, even disdainful, to life, including life in the human fetus.",163 Gonzales also found a legitimate "interest in protecting the integrity and ethics of the medical profession," 164 an interest similarly highlighted in the Stenberg dissent. ${ }^{165}$

Justice Kennedy's opinion in Gonzales likewise echoed his Stenberg dissent in affirming a federal interest in drawing a line between abortion and infanticide. ${ }^{166}$ The legitimacy of such an interest is perhaps suggested by the recent publication in the Journal of Medical Ethics of an article in which the authors argue that "what we call 'after-birth abortion' (killing a newborn) should be permissible in all the cases where abortion is, including cases where the newborn is not disabled." 167 The authors "propose to call this practice "after-birth abortion', rather than 'infanticide', to emphasise [sic] that the moral status of the individual killed is comparable with that of a fetus (on which 'abortions' in the traditional sense are performed) rather than to that of a child."168 Justice Kennedy's Gonzales opinion found the federal ban on partial-birth abortion justified in part by an interest in countering such arguments. ${ }^{169} \mathrm{He}$ quoted with approval the congressional findings that partial birth abortion "had a "disturbing

159. Id. at 147 .

160. Id.

161. Id. at 157; see also supra text accompanying notes 147-50 (discussing in Stenberg the states' sociological interests and interest in protecting the medical profession).

162. Gonzales, 550 U.S. at 157 (quoting congressional finding that "[i]mplicitly approving such a brutal and inhumane procedure by choosing not to prohibit it will further coarsen society to the humanity of not only newborns, but all vulnerable and innocent human life, making it increasingly difficult to protect such life").

163. Stenberg v. Carhart, 530 U.S. 914, 961 (2000) (Kennedy, J., dissenting).

164. Gonzales, 550 U.S. at 157 (quoting Washington v. Glucksberg, 521 U.S. 702, 731 (1997))

165. Stenberg, 530 U.S. at 961 (Kennedy, J., dissenting).

166. Gonzales, 550 U.S. at 158.

167. Alberto Giubilini \& Francesca Minerva, After-Birth Abortion: Why Should the Baby Live?, J. MED. ETHICS 1 (Feb. 23, 2012), available at http:/jme.bmj.com/content/early/2012/03/01/medethics-2011-100411 .full.pdf + html (on file with the McGeorge Law Review).

168. Id. at 2 .

169. See Gonzales, 550 U.S. at 158. 
similarity to the killing of a newborn infant," and that Congress "was concerned with 'draw[ing] a bright line that clearly distinguishes abortion and infanticide." ${ }^{170}$ Significantly, this justification for the federal statute only works as to previability abortions if one sees a strong kinship between the previable fetus and a newborn infant, such that killing the former after partial delivery would be confusingly similar to killing the latter after birth.

\section{E. Justice Kennedy and the Future of the Viability Rule}

The extent to which states may regulate second-trimester abortions depends in significant part on the Supreme Court's future treatment of the viability rule. In Webster, Justice Kennedy joined an opinion that criticized the viability rule, while dicta in Casey purported to reaffirm the rule, albeit in a significantly lesspotent form than the version embraced in Roe..$^{171}$ Justice Kennedy's opinions in Stenberg and Gonzales recognized substantial justifications for state regulation of late-term abortions, even before fetal viability. ${ }^{172}$ Going forward, a significant question will be the Court's willingness to revisit the role of viability in abortion law as states enact second-trimester regulations.

In a future case involving late-term abortions, Justice Kennedy could read his Stenberg and Gonzales opinions in a manner consistent with the treatment of viability in the Casey plurality. Justice Kennedy carefully drafted both opinions on the assumption that Casey-including its dicta on viability-embodied the controlling constitutional standards. ${ }^{173}$ At the same time, there is much in Justice Kennedy's Stenberg and Gonzales opinions that creates tension with the viability rule, and makes it more difficult to justify that rule in constitutional terms. Therefore, I will discuss at least two paths Justice Kennedy might take if he finds the viability rule incompatible with legitimate state interests supporting regulation of late-term abortions.

\section{New State Interests and the Duration of Abortion Rights}

One theme of Justice Kennedy's Stenberg dissent was that, in justifying abortion regulations, states should not be limited to the two narrow state interests identified by the Roe Court. ${ }^{174} \mathrm{He}$ understood Casey to stand for the proposition

170. Id. (citations omitted).

171. See Planned Parenthood of Se. Pa. v. Casey, 505 U.S. 833, 873 (1992); Webster v. Reprod. Health Servs., 492 U.S. 490,517 (1989); Roe v. Wade, 410 U.S. 113, 164 (1973).

172. See Stenberg v. Carhart, 530 U.S. 914, 961 (Kennedy, J., dissenting); Gonzales, 550 U.S. at 15758.

173. See, e.g., Gonzales, 550 U.S. at 146 ("Casey, in short, struck a balance. The balance was central to its holding. We now apply its standard to the cases at bar.").

174. Stenberg, 530 U.S. at 962 (asserting that the state has an interest in protecting the reputation 
that it is "inappropriate for the Judicial Branch to provide an exhaustive list of state interests implicated by abortion." 175 This broadened view of permissible state interests justifying abortion regulations appeared to underlay the majority opinion in Gonzales. ${ }^{176}$ The federal statute ${ }^{177}$ was not upheld solely on the basis of Roe's concern for the "potential life" of the unborn fetus. ${ }^{178}$ Rather, the Court saw the statute as furthering a multiplicity of state interests distinct from the interest in protecting the life of any particular fetus. ${ }^{179}$ The statute was thought to preserve respect for human life among the public and the medical profession, protect the ethics and reputation of medical personnel, and clarify the distinction between abortion and infanticide. ${ }^{180}$

Notwithstanding the majority's recognition of these new state interests justifying regulation of abortion, the Gonzales opinion "assumed" that the viability rule would remain the measure of the duration of abortion rights. ${ }^{181}$ However, there is no particular reason this should be the case, and many reasons to believe it should not. Roe's dicta on the duration of abortion rights took the position that the point at which a particular state interest would justify substantial restrictions on abortion depended on the particular state interest in question. ${ }^{182}$ Thus, an interest in promoting maternal health justified regulation at the end of the first trimester, when abortion might present a greater risk to the mother's health than carrying a child to term. ${ }^{183}$ The interest in protecting fetal life justified regulation only at viability, ${ }^{184}$ though for reasons the Court did not articulate. ${ }^{185}$ Just as the states could assert the distinct interests recognized in Roe at different points in pregnancy, now that Gonzales permits states to advance previously unrecognized interests in support of abortion regulations, ${ }^{186}$ there is no reason all of those interests should be subject to the same durational line.

Consider, for example, the state laws passed in a number of jurisdictions forbidding most abortions after twenty weeks of pregnancy on the theory that the fetus can feel pain at that stage of development. ${ }^{187}$ Assuming the Court finds

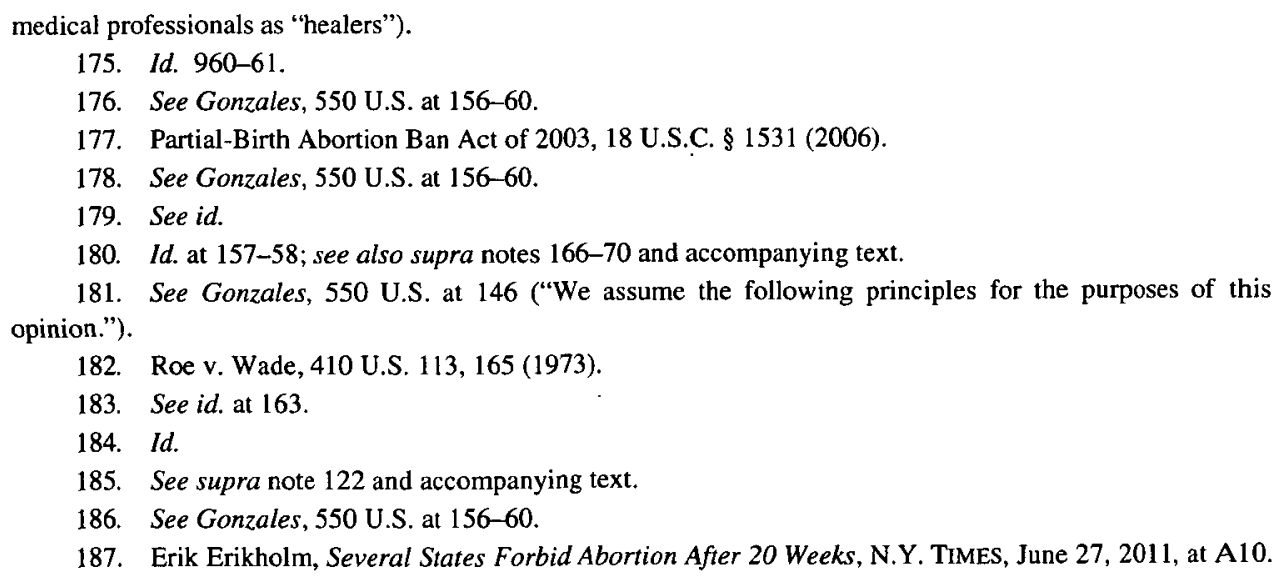


prevention of fetal pain to be a legitimate state interest, there seems to be no reason why viability would prove particularly relevant to the permissibility of state laws premised on that interest. There does not appear to be any logical connection between the ability of the fetus to feel pain, which depends more on neurological development, ${ }^{188}$ and the ability of the fetus to live outside the womb, which depends more on the development of respiratory capacity. ${ }^{189}$ The Court could appropriately confine the viability rule to the state interest the Court designed the rule to cover, a purely moral assessment of the value of unborn human life, and recognize different durational limits for the new state interests now permitted under Gonzales.

\section{Stare Decisis and the Duration of Abortion Rights}

Should a case concerning state regulation of previability, late-term abortions come before the Court, another path open to the Justices would be reconsideration of the viability rule. In an article on the rule of stare decisis, I argue that the viability rule does not merit treatment as binding precedent. ${ }^{190}$ The article highlights three factors that have led the Court to deny or accord diminished precedential weight to rules articulated in prior opinions. First, the viability rule constituted dictum when announced in Roe and when reaffirmed in the Casey plurality opinion. ${ }^{191}$ Both Roe and Casey concerned abortion regulations applicable from the outset of pregnancy, so neither case required the Court to determine the duration of abortion rights in order to resolve the constitutional issues presented. ${ }^{192}$ Second, the Court has been more willing to reconsider rules announced without plenary briefing and argument. ${ }^{193}$ Since the duration of abortion rights was not at issue in Roe or Casey, the briefing and argument in those cases did not focus on the merits of viability as compared to other possible lines governing the duration of abortion rights. ${ }^{194}$ Nor did the Court

Evidence suggesting that the risk of medical complications from abortion increases as gestational age advances may provide additional support for such statutes. See, e.g., Linda A. Bartlett et al., Risk Factors for Legal Induced Abortion-Related Mortality in the United States, 103 OBSTETRICS \& GYNECOLOGY 729, 735 (2004) ("The risk factor that continues to be most strongly associated with mortality from legal abortion is gestational age at the time of the abortion."); id. at 733 (table showing significant increase in risk of mortality when abortion performed at twenty-one weeks or beyond).

188. See Emily Sohn, Do Fetuses Feel Pain?, Discovery News (Apr. 26, 2010), http://news. discovery.com/human/fetus-pain-abortion-law.html (on file with the McGeorge Law Review).

189. See Planned Parenthood of Se. Pa. v. Casey, 505 U.S. 833, 860 (1992) (hypothesizing about the possible effect on the point of viability of future enhancement of "fetal respiratory capacity").

190. See Beck, Transtemporal Separation of Powers, supra note 15, at 1460-64.

191. Id. at $1460-63$.

192. Id.

193. See id. at 1434-39 (illustrating that the Court has afforded less precedential weight to rules not adequately briefed or argued).

194. See id. at 1462-63. 
consider the possibility of dispensing with a one-size-fits-all line drawn by the judiciary. Perhaps instead of the Court drawing a single line to govern abortion rights nationwide, the Court should permit states to experiment with different regulatory regimes, and legislative lines, along with other factors, should be considered in deciding whether a particular state has unduly burdened abortion rights. Third, the Court has been more willing to revisit rulings that have not been adequately defended in a written opinion. ${ }^{195}$ Roe offered no defense of the viability rule, while the brief defense provided in Casey raises unanswered questions and has arguably been undermined by the subsequent opinion in Gonzales. ${ }^{196}$

Several of the "prudential and pragmatic considerations" that the Casey plurality saw as favoring retention of Roe's right to an abortion instead support reconsideration of the viability rule. ${ }^{197}$ For instance, Casey concluded that Roe has not proven "unworkable."198 Even if we accept this conclusion with respect to the basic constitutional right to an abortion, one can make a much stronger argument that viability constitutes an unworkable line if the goal is to enforce state regulations of late-term abortions. Recall the Colautti Court's emphasis on "the uncertainty of the viability determination," "the number and the imprecision of [the relevant] variables," the "difficulty" of determining whether a particular fetus is viable, the different probabilities of survival doctors equate with viability, and the likelihood "that experts will disagree over whether a particular fetus in the second trimester has advanced to the stage of viability." 199 Strikingly, research shows that the doctor's prediction concerning viability is itself a factor significantly affecting the survival prospects of extremely low birth-weight infants. ${ }^{200}$ The imprecision of the viability line will make it very difficult in some cases to prove beyond a reasonable doubt that a particular doctor knew he or she was aborting a viable fetus. In his Stenberg dissent, Justice Kennedy criticized "cases decided in the wake of Roe . . . which gave a physician's treatment decisions controlling weight." ${ }^{201}$ The viability rule seems subject to the same critique, deferring to the physician's judgment to such a degree that it undermines the goal of regulating the physician's conduct.

195. Id. at $1439-47$.

196. See Beck, Gonzales, Casey and the Viability Rule, supra note 23, at 267-79 (discussing the holes in the analytical framework of Roe and Casey and the status of the viability rule in light of Gonzales).

197. Planned Parenthood of Se. Pa. v. Casey, 505 U.S. 833, 854 (1992).

198. Id. at 855 .

199. Colautti v. Franklin, 439 U.S. 379, 395-96 (1979).

200. See Beck, Gonzales, Casey and the Viability Rule, supra note 23, at 260 (quoting Jay D. Iams, Preterm Birth, in SteVen G. GabBe ET AL., OBSTETRICS: NORMAL AND PROBlem PREGNANCIES 755, 812 (4th ed. 2002)).

201. Stenberg v. Carhart, 530 U.S. 914, 968 (2000) (Kennedy, J., dissenting). 
Another factor the Casey plurality considered was reliance on the right to abortion. ${ }^{202}$ The plurality recognized that Roe had not engendered the sort of investment-based reliance one might find in the commercial sphere. ${ }^{203}$ But the plurality believed individuals had "organized intimate relationships and made choices that define their views of themselves and their places in society" based on the assumption that abortion would be an available option "in the event that contraception should fail." ${ }^{204}$ Even assuming this is the case, it is much less plausible that anyone has made such personal or professional decisions in reliance on the viability rule. The ability to terminate an unintended pregnancy might influence decisions about relationships or career choices, but it is much less likely that such decisions would turn on whether the right to abortion continues through the second trimester.

In reaffirming Roe's right to an abortion, the Casey plurality concluded that "[n]o evolution of legal principle has left Roe's doctrinal footings weaker than they were in 1973." ${ }^{205}$ It would be hard to say the same about the viability rule. Starting with Webster, the Court's decisions (including Casey itself) have greatly diminished the significance of fetal viability in evaluating state abortion regulations. ${ }^{206}$ Webster seemingly departed from earlier decisions interpreting the viability rule when it permitted Missouri to create a rebuttable presumption of viability at twenty weeks of pregnancy and to guide the physician's discretion in considering factors relevant to viability. ${ }^{207}$ Though Casey purported to reaffirm the viability rule, it simultaneously deprived the rule of its earlier force, concluding that Roe had significantly undervalued the state interest in unborn human life by preventing previability regulation ${ }^{208}$ Gonzales cast further doubt on the premises underlying the viability rule. ${ }^{209}$ Gonzales permitted a ban on the intact D\&E procedure prior to fetal viability, leading Justice Ginsburg to charge that the majority had "blur[red] the line, firmly drawn in Casey, between previability and postviability abortions." ${ }^{210}$ The Gonzales Court permitted the previability ban based in part on a state interest in distinguishing abortion and infanticide. ${ }^{211}$ This argument implicitly analogizes the previable fetus to a newborn infant and undermines the assumption that some significant change makes the fetus more valuable or worthy of protection once it crosses the

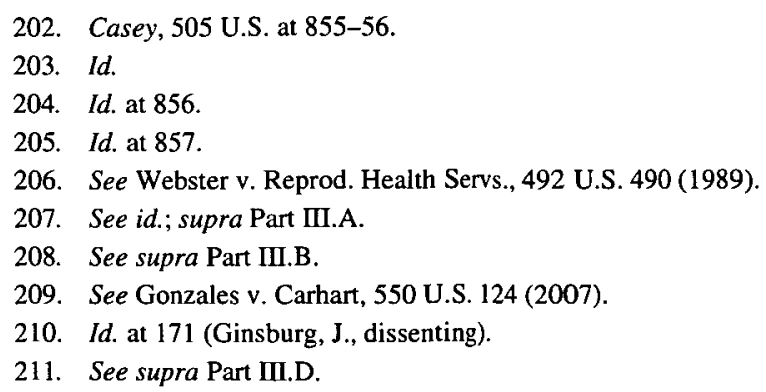


viability threshold. In light of Gonzales, it is not clear why the state should have a sufficient interest in the life of a previable fetus to protect it from death by one means, but not to protect it from death by other means that may be "no less distressing or susceptible to gruesome description."212

The fourth factor the Casey plurality considered concerned whether any factual assumptions underlying the Roe decision had been undermined. ${ }^{2 / 3}$ Here, the plurality acknowledged that viability occurred at an earlier point in pregnancy than at the time of Roe, but decided that this was not critical to the validity of the viability rule:

[T] he divergences from the factual premises of 1973 have no bearing on the validity of Roe's central holding, that viability marks the earliest point at which the State's interest in fetal life is constitutionally adequate to justify a legislative ban on nontherapeutic abortions. The soundness or unsoundness of that constitutional judgment in no sense turns on whether viability occurs at approximately 28 weeks, as was usual at the time of Roe, at 23 to 24 weeks, as it sometimes does today, or at some moment even slightly earlier in pregnancy, as it may if fetal respiratory capacity can somehow be enhanced in the future. Whenever it may occur, the attainment of viability may continue to serve as the critical fact, just as it has done since Roe was decided; which is to say that no change in Roe's factual underpinning has left its central holding obsolete, and none supports an argument for overruling it. ${ }^{214}$

This discussion highlights why the Casey plurality might have done well to wait for a case involving late-term abortions before trying to determine the duration of abortion rights. ${ }^{215}$ Since the durational issue was not important to a ruling on the validity of the Pennsylvania provisions at issue in Casey, the record had not been prepared with late-term abortions prominently in view, obscuring the consequences of a decision reaffirming the viability rule. ${ }^{216}$ In a case where the continuing potency of the viability rule was important to the outcome, the record and briefing might have focused the Court on a great number of facts about viability and late-term abortion methods that were simply not highlighted for the Court at the time of Roe or Casey. In neither Roe nor Casey, for instance, did the Court exhibit awareness of the racial and gender disparities characterizing fetal viability and the consequent disparities in the duration of abortion rights

212. Stenberg v. Carhart, 530 U.S. 914, 951 (2000) (Ginsburg, J., concurring).

213. Planned Parenthood of Se. Pa. v. Casey, 505 U.S. 833, 860 (1992).

214. Id.

215. See id.

216. See id. 


\section{3 / State Interests and the Duration of Abortion Rights}

under the Court's opinions. ${ }^{217}$ Neither case mentioned the role played by irrelevant behavioral and environmental factors. ${ }^{218}$ Neither reflected awareness of the distressing procedures currently used in second-trimester abortions. ${ }^{219}$

The viability rule presents a classic example of the Court applying a rule concerning an issue the Court has never "squarely addressed."220 The Court adopted the viability rule in dicta in Roe and reaffirmed the rule in dicta in Casey. ${ }^{221}$ The Court has never considered the merits of the viability rule based on plenary briefing and argument in a case where it mattered to the outcome. Consequently, the Court has never been required to grapple with the rationale for the viability rule, the strange consequences it produces for constitutional law, or the extreme implications it carries for late-term abortions. Given the Court's acknowledged obligation to "justify the lines we draw," examination to occur, ${ }^{223}$ and the rule of stare decisis should present no barrier to the Court's fulfillment of that obligation.

\section{CONCLUSION}

No Justice currently on the Supreme Court has had as great an impact on the constitutional law of abortion as Justice Kennedy. His views may play a central role in evaluating the constitutional validity of state laws regulating late-term abortions. His opinions leave room for multiple outcomes should the Court squarely face a case calling into question the continuing vitality of the viability rule.

217. See id.; Roe v. Wade, 410 U.S. 113 (1973).

218. See Casey, 505 U.S. 833; Roe, 410 U.S. 113.

219. See Casey, 505 U.S. 833; Roe, 410 U.S. 113. Indeed, at the time of Roe, the methods of abortion at issue in cases like Stenberg and Gonzales were not yet in common use. See Planned Parenthood of Cent. Mo. v. Danforth, 428 U.S. 52, 75-79 (1976). Three years after Roe, the Court reported that the most common method used for second trimester abortions was saline amniocentesis. See id.

220. Harper v. Va. Dep't of Taxation, 509 U.S. 86, 118 (1993) (O'Connor, J., dissenting); Brecht v. Abrahamson, 507 U.S. 619, 631 (1993); Copperweld Corp. v. Independence Tube Corp., 467 U.S. 752 (1984); Beck, Transtemporal Separation of Powers, supra note 15, at 1464.

221. Casey, 505 U.S. 833; Roe, 410 U.S. 113.

222. Casey, 505 U.S. at 870.

223. Beck, Gonzales, Casey and the Viability Rule, supra note 23 , at 279-80. 